\title{
A new species of the millipede genus Nannorrhacus Cook, 1896 from the island of Martinique, Lesser Antilles (Diplopoda: Polydesmida: Platyrhacidae)
}

\author{
Sergei I. GoLOVATCH ${ }^{1}$, Romain SABrOUX ${ }^{2}$, Jean-Paul MAURIÈs ${ }^{3}$, Jean-Jacques GEOFFroY ${ }^{4}$ \\ ${ }^{1}$ Institute for Problems of Ecology and Evolution, Russian Academy of Sciences, Leninsky prospekt 33, Moscow \\ 119071 Russia, e-mail: sgolovatch@yandex.ru \\ ${ }^{2}$ Université Pierre et Marie Curie, Master Systématique Evolution Paléontologie (UPMC-MNHN), 4, place Jussieu, \\ Paris 75005 France; e-mail: romain.sabroux@etu.upmc.fr \\ ${ }^{3}$ Muséum national d'Histoire naturelle, Département Systématique et Evolution, 61, rue Buffon, Paris 75231 France, \\ e-mail: mauries.jean-paul@wanadoo.fr \\ ${ }^{4}$ Muséum national d'Histoire naturelle, Département Ecologie \& Gestion de la Biodiversité, UMR 7204 CESCO, \\ CNRS-MHNH-UPMC, 4, avenue du Petit Chateau, Brunoy 91800 France, e-mail: geoffroy@mnhn.fr
}

\begin{abstract}
Nannorrhacus parvus sp. $\mathrm{n}$. from Martinique, only the 2nd congener, is just the 4th species of the family Platyrhacidae to be found in the Antilles. It differs from N. Iuciae (Pocock, 1894), from St. Lucia, Lesser Antilles, by the following characters: a smaller size; presence of 3 or 2 transverse rows of larger setigerous tubercles on collum and postcollum metaterga, respectively; absence of areations on metaterga; far more strongly tuberculate lateral edges of paraterga; ventrolateral location of ozopores; underdeveloped pleurosternal carinae; and shorter and stouter gonopods.
\end{abstract}

Key words: diplopod, Nannorrhacus, taxonomy, new species, Martinique

\section{INTRODUCTION}

Recently, while sorting out the collections of Diplopoda from the Caribbean island of Martinique, housed in the Muséum national d'Histoire naturelle, Paris, we have been surprised to come across a species of the family Platyrhacidae. This fairly diverse family currently contains about 250, mostly large-bodied species (ca 30-130 mm long) from 40 genera belonging to 7 subfamilies/tribes and living in two highly disjunct areas: the main one, Oriental, from Myanmar and Indochina through Malay Peninsula, Indonesia and the Philippines, to New Guinea with some adjacent archipelagos of Melanesia and one, Palau, in Oceania; the second area, far less speciose, is Neotropical, extending from the Antilles and Nicaragua in the north to Peru and central Brazil in the south (Hoffman 1978, Jeekel 2007, Hoffman et al. 2011, Hoffman \& Martínez-Torres 2012, Shelley \& Martínez-Torres 2013). The Antillean fauna has recently been summarized (Shelley \& Martinez-Torres 2013) and shown to comprise only three genera and species: Hoffmanorhacus sahlii (Jeekel, 1980), from Guadeloupe, Proaspis aitia Loomis, 1941, from Haiti, Hispaniola, and Nannorrhacus luciae (Pocock, 1894), from St. Lucia.

The present paper puts on record the first platyrhacid from Martinique, a new species representing Nannorrhacus Cook, 1896, only the second congener to be found. Its description is provided below.

\section{MATERIAL AND METHODS}

All material derives from a few montane, rather remote localities, taken mostly by JPM. The samples have been shared between the collections of the Muséum national d'Histoire 
naturelle (MNHN), Paris, France, the Zoological Museum of the State University of Moscow (ZMUM), Russia, and the Virginia Museum of Natural History (VMNH), Martinsville, Virginia, USA, as indicated below.

\section{DESCRIPTION}

\section{Nannorrhacus parvus sp. $n$.}

(Figs 1-5)

Holotype $\delta$ (MNHN JB 252), Lesser Antilles, Martinique Island, Macouba, northern slope of Mount Pelée Massif, Morne Macouba, 900-1100 m a.s.1., prairie, mosses and stones, 25.02.1981, leg. J.-P. Mauriès.

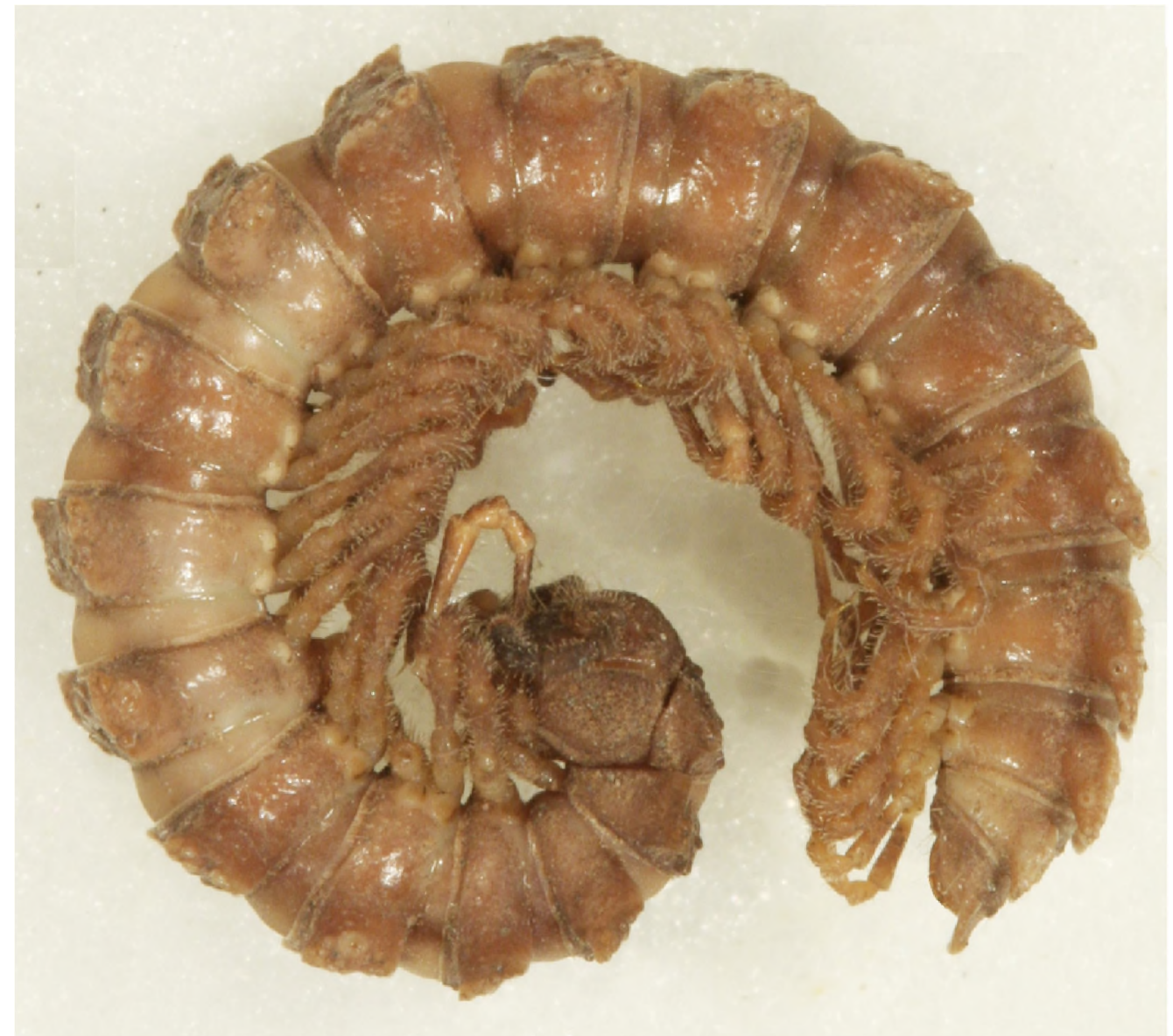

Fig. 1. Nannorrhacus parvus sp. n., ठ holotype, habitus, lateral view. Picture by A. Sysoev, taken not to scale.

Paratypes: $9 \hat{\jmath}, 10$ 우, 2 juv. (MNNH JB 252), $6 \hat{\jmath}, 2$ 우 (ZMUM 22374$), 1 \hat{\jmath}, 1$ ㅇ (VMNH), same locality, together with holotype; 2 우 (MNNH JB 252), L'Ajoupa-Bouillon, Mount Pelée, L'Aileron, under tree, grassy lawn in tropical forest, $1050 \mathrm{~m}$ a.s.1., 22.03.1977, leg. C. Juberthie; $1 \curvearrowright$ (MNNH JB 252), Gros Morne, 6 km NW of Gros Morne, forest between 
Morne Bellevue and Morne de l'Etang, 600-690 m a.s.l., dead leaves and wood, 11.02.1981; 1 क (MNNH JB 252), Schoelcher, Plateau Concorde, ca $600 \mathrm{~m}$ a.s.l., rotten wood and dead leaves, 23.02.1981; $4 \hat{\delta} \hat{\jmath}, 4$ 우 (MNNH JB 252), Case-Pilote, path between Plateau Concorde and Morne Chapeau Nègre, ca 650-850 m a.s.l., dead wood and leaves, 23.02.1981; 1 (MNNH JB 252), Fonds Saint-Denis, Pitons du Carbet, between ribs, 1100 and $1120 \mathrm{~m}$ a.s.1., SSW of Piton Boucher, mosses and dead wood, 27.02.1981; 2 우 (MNNH JB 252), Fonds Saint-Denis, Pitons du Carbet, between Pitons Boucher and Lacroix, bromeliads fallen to ground, 1000-1100 m a.s.1., 27.02.1981; 1 $\hat{\text {, }, 1}$ \% , 1 juv. (MNNH JB 252), Fonds SaintDenis, path down from Piton Boucher, small hollow, $950 \mathrm{~m}$ a.s.l., mosses, 19.11.1983, all leg. J.-P. Mauriès.

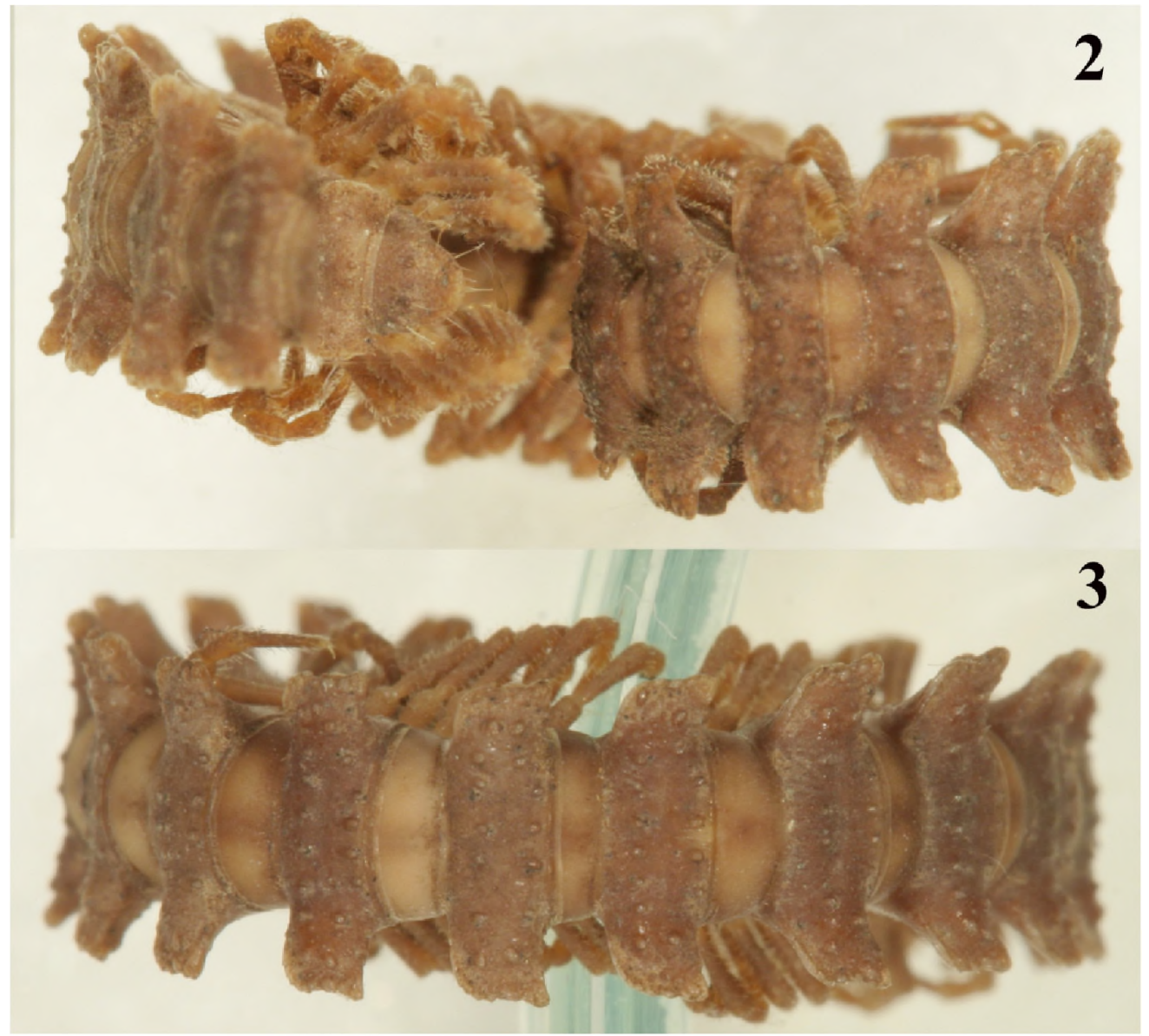

Figs 2 \& 3. Nannorrhacus parvus sp. n., $\delta$ holotype. 2 - anterior and posterior body parts, dorsal view; 3 - middle body part, dorsal view. Pictures by A. Sysoev, taken not to scale.

Name: To emphasize the smaller size of the new species.

Diagnosis: Differs from $N$. luciae (Pocock, 1894), the only hitherto known congener, by the smaller size, the presence of 3 or 2 transverse rows of larger setigerous tubercles on the collum and postcollum metaterga, respectively, as well as the absence of metatergal areations, the more strongly tuberculate lateral edges of the paraterga, the ventrolateral location of the 
ozopores, the underdeveloped pleurosternal carinae, and the shorter and stouter gonopod, especially the acropodite distal to the prefemoral part and the solenophore tooth (sph) (cf. Figs $4,5 \& 6)$.

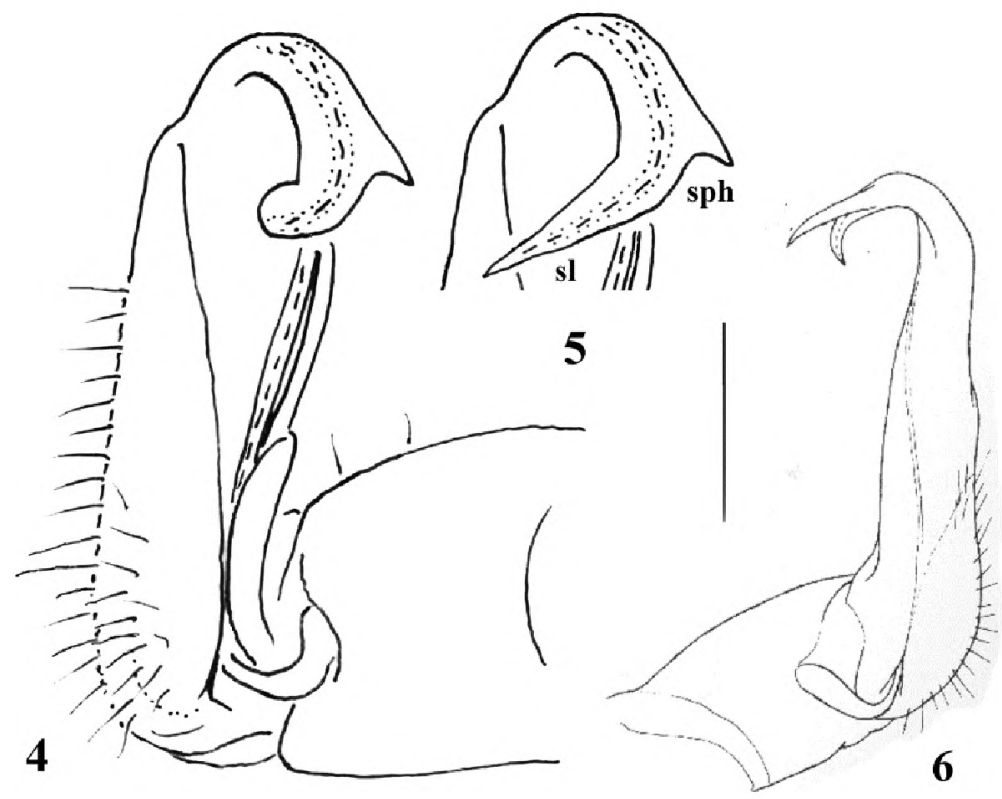

Figs 4-6. Nannorrhacus paruus sp. n., two $\delta$ paratypes (4 \& 5), and N. luciae (Pocock, 1894), ठ from St. Lucia Island (6): 4 -right gonopod, mesal view; 5 - tip of right gonopod, mesal view; 6 -left gonopod, mesal view. Scale bar: 0.25 mm (4 \& 5). Reproduced not to scale (6), courtesy R. M. Shelley.

Description: Length ca $27-31 \mathrm{~mm}$, width on midbody pro- and metazonae $2.2-2.5$ and $3.6-4.1 \mathrm{~mm}$, respectively $(\hat{\partial}, q)$. Holotype ca $30 \mathrm{~mm}$ long, 2.4 and $4.0 \mathrm{~mm}$ wide on midbody pro- and metazonae, respectively. Coloration of alcohol material rather uniformly reddish brown (Figs 1-3) to creamy beige, only antennae (except for distal part of antennomere 6 and entire antennnomeres 7 and 8 ) sometimes dark brown; metaterga only randomly and sometimes encrusted with a darker soil.

Tegument mostly dull, densely granulate throughout, including head behind labrum, prozonae, stricture between pro- and metazonae, venter and legs. Head with $7(8)+7(8)$ labral, $2(3)+2(3)$ supra-labral and 1+1 vertigial tufts of setae; epicranial suture deep. Antennae rather short, only slightly clavate, extending behind body segment 2 when stretched dorsally $(\hat{O}, q)$, with 4 terminal sensory cones, but no other evident sensory structures; relative lengths of antennomeres $6>5=4=3=2>1>7$. In width, head $<$ collum $<$ segment $2<3<4<5=15$ (both sexes), body gently and gradually tapering thereafter. Collum semi-lunar, with three transverse rows of larger, rounded, setigerous tubercles: $2+2$ in anterior, $2+2$ in intermediate, and $5+5$ in posterior row; caudal corner of collum's paraterga rather narrowly rounded, not extending behind rear margin; lateral edge with 7 or 8 similarly setigerous tubercles or larger granulations along caudal $2 / 3$ extent culminating in a tight caudolateral cluster of 3 tubercles. Postcollum metaterga without areations, but with 2 transverse, more or less regular rows of larger, 
rounded, setigerous tubercles, usually $2(3)+2(3)$ per row between bases of paraterga (Figs $2 \&$ 3). Paraterga well-developed, set high (at about upper $1 / 4$ body height), mostly slightly upturned $(\hat{\delta},+)$, pore-bearing ones moderately emarginated at about midway; lateral edge roughly tuberculate/granulate; anterior corners obtuse and especially broadly rounded, caudal corners acute and projecting increasingly farther behind caudal tergal margins from segment 14 , but never sharply acute; dorsum between paraterga only slightly convex (Figs 1-3). Tergal setae borne on larger metatergal tubercles very short, microscopic. Pore formula normal, ozopores on ventrolateral rounded disks in about caudal $1 / 3$ of paraterga (Fig. 1). Limbus microcrenulate. Epiproct (Figs 1 \& 2) long, strongly flattened dorsoventrally, without impressions, regularly rounded and spade-shaped. Hypoproct semi-circular, tufts at caudal edge well-separated.

Sterna narrow in front of gonopods, but broad and nearly flat behind. Legs long, 1.4-1.5 times as long as body height $(\hat{\partial}, \phi)$, but in $\hat{\delta}$ clearly thicker than in $\phi$; in length, femora $=$ tarsi $>$ prefemora $>$ postfemora $=$ tibiae. Gonapophyses opening on ventro-apically swollen 8 coxae 2.

Gonopods (Figs $4 \& 5$ ) very simple and robust. Coxite short and subcylindrical, with 2 dorsolateral setae. Telopodite stout and short, biramous, mostly taken up by an elongated prefemoral (= densely setose) part; acropodite demarcated from the latter by a strong, oblique, mesal sulcus, being short, strongly curved mesad; solenomere (sl) apically rounded to acuminate, located distal to a small tooth (= tibiotarsus, $=$ solenophore) (sph).

Remarks: This species seems to be quite a local endemic of Martinique.

\section{Discussion}

There are two traits in $N$. parvus sp. n. which deserve special attention. Firstly, the ventrolateral location of the ozopores seems to be unique in the entire family Platyrhacidae. However, we refrain from creating still another monobasic Neotropical platyrhacid genus, since most of the other characters of the new species, especially gonopod ones (cf. Figs 4, $5 \& 6$ ), definitely bring it closer to $N$. luciae than to any other genus. So we prefer a more conservative approach and wish to emphasize the particularly close affinities of both these species.

A unique location of the ozopores seems too often to be overestimated. Thus, the dorsal position of the ozopores in the monotypic genus Dorsoporus Loomis, 1958, hitherto known only from the female holotype from Panama, prompted Loomis (1958) to establish the new family Dorsoporidae Loomis, 1958, which is still accepted, but with serious reservations until its male characters have been documented (Hoffman et al. 1996). Similar things are observed in certain Paradoxosomatidae, e.g. the "dragon millipede" genus Desmoxytes Chamberlin, 1923 (Orthomorphini) and a few other, not too closely related genera from the tribes Tectoporini, Eustrongylosomatini and Antichiropodini, some species of which show antler-shaped or spiniform paraterga. The ozopores in such species are also lateral to ventrolateral in position, but no-one argues this character to be only species-specific in these cases (e.g. Golovatch et al. 2012). On the other hand, Jeekel (1983) described a monotypic paradoxosomatid genus, Pleuroporodesmus Jeekel, 1983, again based only on a few females which bear the ozopores below the paraterga. At the opposite extreme, however, within the family Cryptodesmidae the ozopores if any can lie dorsally or ventrally on paraterga depending on species and segment number (Golovatch et al. 2010).

The second remarkable trait is individual variation in shape of the solenomere tip, it being from rounded to acuminate (Figs $4 \& 5$ ). Such a variation also seems to be unique in Platyrhacidae. 


\section{ACKNOWLEDGEMENTS}

Alexandr Sysoev (Moscow, Russia) very skillfully took all pictures. Special thanks go to the MNHN administration for financing the first author's stay in Paris in March and April 2014. We are greatly obliged to both peer reviewers who helped us considerably improve the paper. Rowland M. Shelley (North Carolina Museum of Natural Sciences, Raleigh, NC, U.S.A.) very kindly allowed us to reproduce his original drawing for comparative purposes.

\section{REFERENCES}

Golovatch S. I., GEofFroy J.-J.., MAURIES J.-P., VANDENSPIEgEL D. 2010. Two new species of the millipede genus Trichopeltis Pocock, 1894 (Diplopoda: Polydesmida: Cryptodesmidae) from Vietnam and China. Arthropoda Selecta 19 (2): $63-72$

GOLOVATCH S. I., LI Y., LIU W., GEOFFROY J.-J. 2012. Three new cavernicolous species of dragon millipedes, genus Desmoxytes Chamberlin, 1923, from southern China, with notes on a formal congener from the Philippines (Diplopoda, Polydesmida, Paradoxosomatidae). ZooKeys 185: 1-17.

HOFFMAN R. L. 1978. On the classification and phylogeny of chelodesmoid Diplopoda. Abhandlungen und Verhandlungen des naturwissenschaftlichen Vereins in Hamburg, N.F., 21/22: 21-31.

HofFMAN R. L. \& MARTÍNEZ-TORRES D. 2012. Amnestorhacus, a new genus in the Neotropical diplopod fauna, based on the forgotten species Arcidesmus ologona Silvestri, 1898 (Polydesmida: Platyrhacidae). Annali del Museo Civico di Storia Naturale "Giacomo Doria" 104: 131-140.

HoffMAN R. L., MARTínez D. \& Florez E. D. 2011. A new Colombian species in the milliped genus Psammodesmus, symbiotic host for bryophytes (Polydesmida: Platyrhacidae). Zootaxa 3015: 52-60.

HoffMan R. L., Golovatch S. I., ADIS J. \& DE MORAIS J. W. 1996. Practical keys to the orders and families of millipedes of the Neotropical region (Myriapoda: Diplopoda). Amazoniana 14(1/2): 1-35.

JEEKEL C. A. W. 1983. Pleuroporodesmus, an aberrant new genus of the family Paradoxosomatidae from Borneo (Diplopoda, Polydesmida). Entomologische Berichten 43: 9-14.

JEEKEL C. A. W. 2007. An annotated bibliographical catalogue of the Indo-Australian Platyrhacidae (Diplopoda, Polydesmida). Myriapod Memoranda 10: 48-101.

LOOMIS H. F. 1958. A new family of millipeds on Barro Colorado Island, Canal Zone. Journal of the Washington Academy of Sciences 48(7): 235-237.

SHELlEy R. M. \& MARTíNEZ-TORRES D. 2013. The milliped family Platyrhacidae (Polydesmida: Leptodesmidea) in the West Indies: Proposal of Hoffmanorhacus n. gen.; description and illustrations of males of Proaspis aitia Loomis, 1941; redescription of Nannorrhacus huciae (Pocock, 1894); hypotheses on origins and affinities; and an updated New World familial distribution. Zootaxa 3626: 477-498.

\section{STRESZCZENIE}

\section{[Nowy gatunek krocionoga z rodzaju Nannorrhacus Cook, 1896 z Martyniki, Mniejsze Antyle (Diplopoda: Polydesmida: Platyrhacidae)]}

Nannorrhacus parvus sp. n. z Martyniki, jest dopiero drugim gatunkiem tego rodzaju i czwartym znalezionym na Antylach a należącym do rodziny Platyrhacidae, o dysjunktywnym zasięgu, w którym glówne bogactwo gatunków pochodzi z obszarów Indonezji. Gatunek różni się od N. luciae (Pocock, 1894), opisanym z Wyspy Św. Łucji (Am. Środkowa, Antyle Mniejsze) następującymi cechami: mniejszy rozmiar, obecność trzech poprzecznych rzędów kolczastych guzków na tergicie segmentu szyjnego oraz dwóch rzędów na metatergitach; nieobecność areacji (wypuklych pól) na metatergitach; bardziej wydatna faktura guzków w bocznych kątach paranota, ventrolateralne umiejscowienie ozoporów; mało wyraźne linie pleurosternalne (carinae); krótsze i grubsze gonopody. Autorzy dyskutują dwie rzadkie cechy: brzuszno-boczne umiejscowienie ozoporów, jakie stwierdzono już w niektórych rodzajach zupełnie innej rodziny oraz osobnicza zmienność kształtu solenomerytu. 